\title{
Constraints in Production and Marketing of Rice in West Godavari District of Andhra Pradesh, India
}

\author{
M. Priyanka Chowdary ${ }^{1 *}$ and S. Hymajyothi ${ }^{2}$ \\ ${ }^{I}$ Department of Agricultural Economics, Agricultural College, Bapatla, AP, India \\ ${ }^{2}$ Department of Agricultural Economics, Agricultural College, Rajamahendravaram, \\ $A P$, India \\ *Corresponding author
}

\begin{abstract}
A B S T R A C T
Keywords

Marketing of Rice,

West Godavari

District,

Constraints in

Production

Article Info

Accepted:

07 May 2019

Available Online:

10 June 2019

The study aims to examine the constraints in production and marketing of paddy in West Godavari district of Andhra Pradesh. Primary data was collected from 120 farmers in eight villages of four mandals through personal interview method with the help of pre-structured schedule for the year 2016-17. Major constraints pertaining to marketing of Rice were Low price for produce, MSP after official and unofficial cut due to quality discrepancy. The constraints pertaining to cultivation are Marginal size of holding leading to lesser production, Lack of drainage facilities were some of the major constraints which were faced by the producers of the study area.
\end{abstract}

\section{Introduction}

The constraints faced by the farmers in production and marketing of rice were identified and analyzed using the Garrett's ranking technique. The production constraints were lack of drainage facilities, marginal size of holdings, scarcity of labour, inadequate institutional credit for production \& marketing. The marketing constraints were low price for produce, lack of awareness on market information, lack of knowledge on grading and standardization, high marketing cost, more distance to market, delayed payment after selling of the produce, non availability of sufficient storage space, more transport losses and existence of more number of middlemen. Analytical findings were presented in Table 1.

\section{Materials and Methods}

The study pertains to Andhra Pradesh state, West Godavari district. Primary data was 
collected from 120 farmers in eight villages of four mandals through interview method with the help of pre-structured schedule in the year 2016-17 regarding different production and marketing constraints faced by farmers. From each selected village 15 farmers cultivating rice were selected randomly making a total sample of 120 farmers and these farmers were post-stratified into small, medium and large farmers based on the total operated farm holdings.

Thus, out of total 120 sample farmers, 62 small farmers with $<2$ hectares of farm holding, 45 medium farmers with the farm holding size of 2- 4 hectares and 13 large farmers with farm holding size of $>4$ hectares formed the final sample categories for data collection.

\section{Garrett's ranking technique}

To identify the major production and marketing constraints faced by the farmers, Garrett's ranking technique was used. According to this, the respondents were asked to assign rank to different problems by using the following formula (Garrett and Woodsworth, 1969):

Per cent position $=\frac{\left[100 *\left(\mathrm{R}_{\mathrm{ij}}-0.50\right)\right]}{\mathrm{N}_{\mathrm{j}}}$

where, $R_{i j}=$ rank given for $i^{\text {th }}$ problem by $j^{\text {th }}$ individual;

$\mathrm{N}_{\mathrm{j}}=$ number of problems ranked by the $\mathrm{j}^{\text {th }}$ individual

\section{Results and Discussion}

\section{Constraints in production and marketing of rice}

From the Table 1, major constraints faced by farmers during production and marketing were low price for produce (69.18), MSP after official and unofficial cut (67.22). marginal size of holding leading to lesser production (64.18), lack of drainage facilities (61.24), scarcity of labour during production and marketing (59.62), non availability of sufficient storage space (54.08).

The other constraints during production and marketing were existence of more number of middlemen (53.56), inadequate institutional credit for production \& marketing (43.18), more distance to market /marketing society (46.42) high marketing cost (45.10), lack of awareness on market information (39.52), lack of knowledge on grading and standardization (35.42), delayed payment after selling of the produce (32.28), more transport losses (29.23). These findings were similar with Prakash (2012) and Thanh and Singh (2006). These findings were also in accordance with Natchimuthu and Umamaheswari (2016), and Anandaraj (2015).

In conclusion, the major constraints faced by farmers during production were marginal size of holding leading to lesser production with mean scores of 64.18, lack of drainage facilities (61.24), scarcity of labour during production and marketing (59.62) and nonavailability of sufficient storage space (54.08).

The major constraints during marketing are, MSP after official and unofficial cut (67.22), high marketing cost (45.10) and lack of awareness on market information (39.52).

\section{Policy implications}

1) The pooling of land by the rice farmers envisaged to obtain the economies of scale of larger production. 
Table.1 Production and marketing constraints faced by sample farmers

\begin{tabular}{|c|l|r|r|c|}
\hline $\begin{array}{c}\text { S. } \\
\text { No. }\end{array}$ & \multicolumn{1}{|c|}{ Constraint } & Scores & $\begin{array}{c}\text { Mean } \\
\text { score }\end{array}$ & Rank \\
\hline $\mathbf{1}$ & High marketing cost & 5412 & 45.1 & IX \\
\hline $\mathbf{2}$ & Low price for produce & 8301 & 69.18 & I \\
\hline $\mathbf{3}$ & More distance to market /marketing society & 5570 & 46.42 & VIII \\
\hline $\mathbf{4}$ & Non availability of sufficient storage space & 6489 & 54.08 & VI \\
\hline $\mathbf{5}$ & More transport losses & 3507 & 29.23 & XIV \\
\hline $\mathbf{6}$ & $\begin{array}{l}\text { Inadequate institutional credit for production } \\
\text { \&marketing }\end{array}$ & 5181 & 43.18 & X \\
\hline $\mathbf{7}$ & Lack of awareness on market information & 4742 & 39.52 & XI \\
\hline $\mathbf{8}$ & Lack of knowledge on grading and standardisation & 4250 & 35.42 & XII \\
\hline $\mathbf{9}$ & Marginal size of holding leading to lesser production & 7701 & 64.18 & III \\
\hline $\mathbf{1 0}$ & Delayed payment of MSP during procurement & 3874 & 32.28 & XIII \\
\hline $\mathbf{1 1}$ & Existence of more number of middlemen & 6427 & 53.56 & VII \\
\hline $\mathbf{1 2}$ & scarcity of labour during production and marketing & 7154 & 59.62 & V \\
\hline $\mathbf{1 3}$ & Lack of drainage facilities & 7349 & 61.24 & IV \\
\hline $\mathbf{1 4}$ & $\begin{array}{l}\text { MSP after official and unofficial cut due to quality } \\
\text { discrepancy }\end{array}$ & 8060 & 67.22 & II \\
\hline
\end{tabular}

The government of India may adopt the recommendation given by National Commission for Farmers (NCF) that MSP should be at least $50 \%$ more than the weighted average cost of production.

Introduction of Direct Payment Deficiency System (DPDS) for paying MSP guarantee for the farmers has to be initiated. Under this system, the farmers will directly get the amount, which is the difference between the Minimum Support Price (MSP) and market price, when the market price falls below the MSP.

\section{References}

Anandaraj, P. 2015. Cost, returns and marketing channels of Paddy in
Thiruvarur district (Tamil Nadu). International Journal of Science and Research. 4 (11): 1634-1639.

Natchimuthu, V and Umamaheswari, R. 2016. The problems of paddy cultivators in Erode District: A case study. International Journal of Research in Humanities and Social Sciences. 3 (1): 52-57.

Prakash, C. 2012. Problems and expectations of the farmers in marketing paddy in Tiruvarur district, Tamilnadu. Asian Journal of Management Research. 3 (1): 253-262.

Thanh, N.C and Singh, B. 2006. Constraints faced by the farmers in rice production and export. Omonrice. 14: 97-110.

\section{How to cite this article:}

Priyanka Chowdary, M. and Hymajyothi, S. 2019. Constraints in Production and Marketing of Rice in West Godavari District of Andhra Pradesh, India. Int.J.Curr.Microbiol.App.Sci. 8(06): 787-789. doi: https://doi.org/10.20546/ijcmas.2019.806.095 